\title{
Celluclast and Cellic ${ }^{\circledR}$ CTec2: Saccharification/fermentation of wheat straw, solid-liquid partition and potential of enzyme recycling by alkaline washing
}

\author{
Ana Cristina Rodrigues ${ }^{\mathrm{a}}$, Mai Østergaard Haven ${ }^{\mathrm{b}, \mathrm{c}}$, Jane Lindedam ${ }^{\mathrm{b}}$, Claus Felby ${ }^{\mathrm{b}}$, \\ Miguel Gama $^{\mathrm{a}, *}$ \\ a Centre of Biological Engineering, University of Minho, Campus de Gualtar, 4710-057 Braga, Portugal \\ b Department of Geosciences and Natural Resource Management, University of Copenhagen, Rolighedsvej 23, DK-1958 Frederiksberg C, Denmark

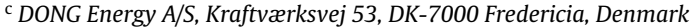

\section{A R T I C L E I N F O}

\section{Article history:}

Received 30 April 2015

Received in revised form 14 June 2015

Accepted 23 June 2015

Available online 17 July 2015

\section{Keywords:}

Cellulases

Enzyme activity stability

Adsorption/desorption

Enzyme recycling

\begin{abstract}
A B S T R A C T
The hydrolysis/fermentation of wheat straw and the adsorption/desorption/deactivation of cellulases were studied using Cellic ${ }^{\circledR}$ CTec2 (Cellic) and Celluclast mixed with Novozyme 188. The distribution of enzymes - cellobiohydrolase I (Cel7A), endoglucanase I (Cel7B) and $\beta$-glucosidase - of the two formulations between the residual substrate and supernatant during the course of enzymatic hydrolysis and fermentation was investigated. The potential of recyclability using alkaline wash was also studied. The efficiency of hydrolysis with an enzyme load of $10 \mathrm{FPU} / \mathrm{g}$ cellulose reached $>98 \%$ using Cellic ${ }^{\circledR} \mathrm{CTec}^{2}$, while for Celluclast a conversion of $52 \%$ and $81 \%$, was observed without and with $\beta$-glucosidase supplementation, respectively. The decrease of Cellic ${ }^{\circledR} \mathrm{CTec} 2$ activity observed along the process was related to deactivation of Cel7A rather than of Cel7B and $\beta$-glucosidase. The adsorption/desorption profiles during hydrolysis/fermentation revealed that a large fraction of active enzymes remained adsorbed to the solid residue throughout the process. Surprisingly, this was the case of Cel7A and $\beta$-glucosidase from Cellic, which remained adsorbed to the solid fraction along the entire process.

Alkaline washing was used to recover the enzymes from the solid residue. This method allowed efficient recovery of Celluclast enzymes; however, this may be achieved only when minor amounts of cellulose remain present. Regarding the Cellic formulation, neither the presence of cellulose nor lignin restricted an efficient desorption of the enzymes at alkaline $\mathrm{pH}$. This work shows that the recycling strategy must be customized for each particular formulation, since the enzymes found e.g. in Cellic and Celluclast bear quite different behaviour regarding the solid-liquid distribution, stability and cellulose and lignin affinity.
\end{abstract} (c) 2015 Elsevier Inc. All rights reserved.

\section{Introduction}

Ethanol is a renewable alternative to petroleum-derived fuels. It can be produced from lignocellulosic materials in various ways, overall consisting of the pretreatment, hydrolysis of cellulose and hemicellulose to monomeric sugars, fermentation and product recovery. Although a significant effort has been made to improve the pretreatment step, an efficient enzymatic hydrolysis still requires high enzyme loadings which contribute to the high costs of the biomass-derived ethanol [1,2]. Researchers attempted

\footnotetext{
* Corresponding author. Fax: +351253678986.

E-mail addresses: ana_cris@deb.uminho.pt (A.C. Rodrigues), maope@dongenergy.dk (M.Ø. Haven), lindedam@life.ku.dk (J. Lindedam), cf@life.ku.dk (C. Felby), fmgama@deb.uminho.pt (M. Gama).
}

to reduce the cost of enzymatic hydrolysis $[3,4]$ by (i) minimizing the costs of enzyme production, (ii) increasing the enzymes specific activity, (iii) reducing the required cellulase loading by pretreating the biomass [5], (iv) or recycling the enzymes for multiple rounds of hydrolysis [2,4,6-13].

Cellulase formulations contain a broad spectrum of enzymes that work synergistically to convert cellulose to simpler sugars, namely endoglucanases, cellobiohydrolases, and $\beta$-glucosidase. The adsorption of cellulases onto the substrate is the first step in cellulose hydrolysis. Henceforward, a portion of the adsorbed cellulases is gradually release into the supernatant $[1,11,12,14]$. At the end of the process, for the cellulases present in the supernatant, the simplest recovery method is re-adsorption onto fresh substrate [15] or collection by ultrafiltration [11,16]. More challenging is the recovery of the portion of cellulases adsorbed on the 
residual substrate, which accounts for $30-90 \%$ of the total enzyme load, depending on the process configuration [14].

Cellulase adsorption onto cellulose is reportedly reversible and often described by the Langmuir isotherm. However, according to various authors, adsorption onto lignin-rich substrates is not strictly reversible $[4,17]$. The addition of a desorbent is a traditional approach to detach the enzymes from a lignocellulosic residue [7]. A range of chemicals can be used for that purpose [12], such as surfactants, urea, alkali, glycerol [18,7,19], and polyethylene glycol [20]. However, most are not effective enough and additionally some of them deactivate the enzymes. Remarkably, alkaline solutions proved to be among the most efficient ones $[4,7,9,10,21]$. In addition, adjusting the $\mathrm{pH}$ is operationally easy and cost-effective.

The successful development of recycling enzyme strategies is generally recognized as highly promising and desirable. However, it requires enzymes to be stable enough to endure several cycles of recycling. Stability critically depend on the temperature used in the process $[10,11,22]$, but also on the $\mathrm{pH}$, shear stress (from agitators, flow and pumps) and on the contact with the air-liquid interface $[23,24]$. Though recycling cellulases can be regarded nowadays as technically feasible, the process must be adapted to each particular enzyme, substrate and operational conditions. We have demonstrated in previous work $[10,11]$ that recycling Celluclast can be easily achieved as long as a temperature below $50^{\circ} \mathrm{C}$ is used and a complete cellulose conversion is achieved. This is possible because after thorough cellulose conversion the enzymes can be recovered from the liquid phase. In this manuscript, we demonstrate that the same is not possible for the highly effective Cellic enzymes, which remain bound to the final residue even after complete hydrolysis, thus making more challenging the recycling process.

\section{Materials and methods}

\subsection{Enzymes and substrate composition}

Enzymatic hydrolysis was carried out using two different enzyme preparations, Celluclast 1.5 FG L combined with $\beta$ glucosidase (Novozyme 188) and Cellic (all from Novozymes A/S, Basgsværd, Denmark). Activity on filter paper fibers was determined as described by Adney and Baker, [25]. Enzyme activities of $223 \mathrm{FPU} / \mathrm{mL}$ and $84 \mathrm{FPU} / \mathrm{mL}$ were obtained, respectively for Cellic and Celluclast.

Wheat straw was hydrothermally pretreated at the Inbicon pilot plant (Skærbæk, Denmark) [26] and the final dry matter content was $30 \%$. The material was stored at $4{ }^{\circ} \mathrm{C}$ until use. The composition of pretreated wheat straw was: $52.82 \%$ cellulose, $2.47 \%$ xylan, $39.03 \%$ lignin Klason and $3 \%$ ash, as determined by strong acidhydrolysis (see Section 2.2.3).

\subsection{Hydrolysis and fermentation}

The hydrolysis and fermentation were performed in $500 \mathrm{~mL}$ Erlenmeyer flasks in an incubator shaker (Unimax $1010 \mathrm{Hei}-$ dolph) with a rotational mixing of $280 \mathrm{rpm}$. Enzymatic hydrolysis was carried out on $150 \mathrm{~mL}$ of $0.1 \mathrm{M}$ sodium acetate buffer (NaAc, Sigma-Aldrich, 32,318) at $\mathrm{pH} 4.8$, using a concentration of biomass (wheat straw) of $12 \%(\mathrm{w} / \mathrm{v})$ on a dry weight basis. Hydrolysis of the biomass was performed at $50^{\circ} \mathrm{C}$ for $96 \mathrm{~h}$, using different enzyme loadings: (A) 10 FPU Celluclast: 20 IU $\beta$-glucosidase (Novozyme 188)/g cellulose; (B) 10 FPU Celluclast/g cellulose; and (C) $10 \mathrm{FPU}$ Cellic/g cellulose. After hydrolysis, the fermentation flasks were cooled down to room temperature and inoculated with yeast Saccharomyces cerevisiae CEN PK 113 wild type with an initial optical density (O.D.600) $=0.5$. Yeast extract and peptone, required for the fermentation stage, where added to a final concentration of 1 and $2 \%(\mathrm{w} / \mathrm{v})$, respectively. The flasks were then incubated at $33^{\circ} \mathrm{C}$ for $48 \mathrm{~h}, 150 \mathrm{rpm}$. All the experiments were carried out under sterile conditions. Samples were taken at the beginning of the assay and every $24 \mathrm{~h}$, up to $144 \mathrm{~h}$. The liquid and solid fractions was separated by centrifuged at $4480 \mathrm{~g}$ for $12 \mathrm{~min}$ (microcentrifuge Sigma, model 113). The liquid phase was recovered and solid fraction was ressuspended in the same volume of liquid fraction removed with fresh $0.1 \mathrm{M}$ NaAc buffer. The supernatant was analysed for sugars and ethanol by HPLC (see Section 2.2.2) and the enzymatic activity distribution associated to the liquid and solid fractions, as well as the total activity, were measured every $24 \mathrm{~h}$ (see Section 2.2.1), in order to evaluate the adsorption/desorption profiles along hydrolysis/fermentation and the thermo stability of Celluclast and Cellic.

After $144 \mathrm{~h}$ of hydrolysis and fermentation the ability of alkaline washing to desorbed the proteins adsorbed on the solid residue obtained was investigated (see Section 2.4).

\subsubsection{Enzyme activity measurements-methylumbelliferyl-assays}

Cel7A, Cel7B and $\beta$-glucosidase activities were measured by fluorescence spectroscopy using a Biotech Synergy HT Elisa plate reader and 4-methylumbelliferyl- $\beta$-D-cellobioside (MUC, Sigma-Aldrich, M6018), 4-methylumbelliferyl$\beta$-D-lactopyranoside (MULac, Sigma-Aldrich, M2405) and 4-methylumbelliferyl- $\beta$-D-glucopyranoside (MUGlc, Sigma-Aldrich, M3633) as substrates, respectively. Upon hydrolysis by Cel7A, Cel7B and $\beta$-glucosidase, the substrates release free 4-methylumbelliferone (MU, Sigma-Aldrich, M1508) resulting in a shift of the fluorescence spectra (excitation maximum/fluorescence maximum), which was quantified for excitation and emission wavelengths of $360 \mathrm{~nm}$ and $460 \mathrm{~nm}$, respectively.

The Cel7A, Cel7B and $\beta$-glucosidase activities were measured by adjusting the protocol published by Bailey and Tähtiharju, [27]. In these assays, $400 \mu \mathrm{L}$ of $1 \mathrm{mM}$ MUC, MULac or MUGlc solutions (in $0.1 \mathrm{M}$ NaAc buffer, $\mathrm{pH} 4.8$ ) were added to $50 \mu \mathrm{L}$ of the test samples (dilutions in NaAc buffer); the mixture was vortexed and incubated at $50^{\circ} \mathrm{C}$ for $15 \mathrm{~min}$. The reaction was then stopped by addition of $550 \mu \mathrm{L} 1.0 \mathrm{M} \mathrm{Na}_{2} \mathrm{CO}_{3}$ buffer (Panreac, 131647.1211) (for Cel7A and $\beta$-glucosidase activity measurements) or $500 \mu \mathrm{L} 1.0 \mathrm{M}$ $\mathrm{Na}_{2} \mathrm{CO}_{3}$ buffer (Panreac, 131647.1211) (for Cel7B activity measurements) and measured on a black bottom 96-well UV fluorescence microplate. Since Cel7A, Cel7B and $\beta$-Glucosidase-all hydrolyze the MULac substrate, the Cel7B activity was measured adding $50 \mu \mathrm{L}$ of a mixture containing $1.0 \mathrm{M}$ glucose and $50 \mathrm{mM}$ cellobiose to the chromophoric substrate MULac, in order to inhibit the Cel7A and $\beta$-glucosidase activities (Van Tilbeurgh et al. [28]).

A $1 \mathrm{mM}$ stock solution of MU was diluted in the range of 0.0001-0.02 mM and used to prepare a standard calibration curve by plotting $\mathrm{MU}$ concentration $(\mathrm{mM})$ versus relative fluorescence units (RFU). The amounts of MUC, MULac and MUGlc hydrolyzed $(\mathrm{mM})$, determined using the calibration curves obtained, were converted to enzyme activity units, (IU/mL), defined as the amount of enzyme that catalyzes the transformation of one micromole of substrate per minute under specified conditions. All experiments were performed in duplicate and repeated twice; the mean values and standard deviations were calculated.

\subsubsection{Sugars and ethanol analysis. All liquid samples taken from} hydrolysis and fermentation were filtered through a $0.2 \mu \mathrm{m}$ filter (PES membrane, Ø $25 \mathrm{~mm}$, VWR, 514-0072) and analysed for cellobiose, glucose and ethanol by HPLC. Chromatographic separation was performed using a Metacarb $87 \mathrm{H}$ column $(300 \times 7.8 \mathrm{~mm}$, Varian, USA) under the following conditions: mobile phase $0.005 \mathrm{M}$ $\mathrm{H}_{2} \mathrm{SO}_{4}$, flow rate $0.7 \mathrm{~mL} / \mathrm{min}$, and column temperature $60^{\circ} \mathrm{C}$. The volume injected was $20 \mu \mathrm{L}$ per sample. 


\subsubsection{Analysis of the wheat straw composition}

The wheat straw was dried at $37^{\circ} \mathrm{C}$ to constant weight. Aliquots from the homogenized residue were subjected to moisture determination and quantitative acid hydrolysis with $5 \mathrm{~mL}$ of $72 \%(\mathrm{w} / \mathrm{w})$ sulphuric acid, for one hour with constant stirring, at $30^{\circ} \mathrm{C}$; the hydrolysate was diluted with water until $148.67 \mathrm{~g}$ and autoclaved at $121^{\circ} \mathrm{C}$ for $1 \mathrm{~h}$. Thereafter, the solid residue obtained was recovered by filtration with crisol Gooch no. 3 and dried at $105^{\circ} \mathrm{C}$ to constant weight; this residue was classified as Klason lignin [29]. The monosaccharides in the liquid fraction were analysed by HPLC (see Section 2.2.2).

\subsubsection{Soluble sugars and ethanol yield}

The glucose yield was calculated according to the NREL standard procedure by Dowe and McMillan [30].

$\%$ Glucose equivalent yield $=\frac{[\text { Glucose }]+1.053 \times[\text { Cellobiose }]}{1.111 \times f \times[\text { Biomass }]}$

$$
\times 100 \%
$$

where [Glucose] and [Cellobiose] are the final glucose and cellobiose concentration $(\mathrm{g} / \mathrm{L})$. [Biomass] is the initial dry biomass weight $(\mathrm{g} / \mathrm{L}) ; f$ is the cellulose fraction of dry biomass $(\mathrm{g} / \mathrm{g})$; The factor 1.053 converts cellobiose to the equivalent amount of glucose.

Ethanol yield $=\frac{[\mathrm{EtOH}]_{f}-[\mathrm{EtOH}]_{0}}{0.51 \times(f \times[\text { Biomass }] \times 1.111)} \times 100 \%$

where $[\mathrm{EtOH}]_{f}$ is the ethanol concentration at the end of fermentation $(\mathrm{g} / \mathrm{L}) .[\mathrm{EtOH}]_{0}$ is the ethanol concentration at the beginning of the fermentation $(\mathrm{g} / \mathrm{L})$. The expression " $0.51 \times(f \times[$ Biomass $] \times 1.111])$ " corresponds to the theoretical ethanol concentration, where [Biomass] is the initial dry biomass weight $(\mathrm{g} / \mathrm{L}) ; f$ is the cellulose fraction of dry biomass $(\mathrm{g} / \mathrm{g})$; 0.51 is the conversion factor for glucose to ethanol based on the stoichiometry of the reaction and 1.111 is the conversion factor of cellulose to equivalent glucose.

\subsubsection{Enzyme activity recovery}

The measured activities of Cel7A, Cel7B and $\beta$-glucosidase were used to evaluate the deactivation of enzymes, the adsorption/desorption profile during hydrolysis and fermentation and finally to determine the enzyme activity recovery from solid fraction, after alkaline washing, as shown in Eq. (3):

Recovery of activity $(\%)=\frac{\text { Measured activity }}{\text { Initial activity }} \times 100 \%$

\subsection{Enzyme adsorption/desorption on pure substrates}

Celluclast and Cellic were added to a $12 \%(\mathrm{w} / \mathrm{v})$ pure lignin suspension (lignin treated according to Rodrigues et al. [10] or $12 \%$ (w/v) cellulose CF 11 (Whatman) to a final loading of $10 \mathrm{FPU} / \mathrm{g}$ dry matter. The substrates, with a total volume of $25 \mathrm{~mL}$ in Erlenmeyer $100 \mathrm{~mL}$ flasks, were placed overnight at room temperature on an incubator shaker at $150 \mathrm{rpm}$.

After overnight incubation, two samples of $1 \mathrm{~mL}$ from every suspension was taken. All samples were centrifuged at $4480 \mathrm{~g}$ for $12 \mathrm{~min}$ (microcentrifuge Sigma, modell 113). One of this sample was measured the activity of Cel7A, Cel7B and $\beta$-glucosidase present in liquid and solid fraction were determined using the methylumbelliferyl assay (see Section 2.2.1). The second sample, the supernatant was then removed and the solid fraction subjected to an alkaline washing treatment to extract the adsorbed enzyme (see Section 2.4). After alkaline treatment the enzymatic activity of Cel7A, Cel7B, and $\beta$-glucosidase were determined using the methylumbelliferyl assay (see Section 2.2.1). All experiments were performed in duplicate and repeated twice; the mean values and standard deviations were calculated.

\subsection{Alkaline washing of adsorbed enzymes}

The solid fraction was re-suspended in alkaline solution of $0.1 \mathrm{M}$ Tris-HCl buffer (Sigma-Aldrich, T87602) at $\mathrm{pH} 9$ and left for $2 \mathrm{~h}$ at room temperature (on a turning wheel at $40 \mathrm{rpm}$, Rotator SB 3-Stuart), supernatant was recovery and solid fraction obtained after alkaline wash was ressuspended in same volume of supernatant recovery in a solution, $1 \mathrm{M} \mathrm{NaAc}$ buffer at $\mathrm{pH} 4.8$. The alkaline washing promotes the desorption of enzymes, as shown elsewhere [10]. The suspension was centrifuged at $4480 \mathrm{~g}$ for $12 \mathrm{~min}$ (microcentrifuge Sigma, modell 113). The samples obtained, both supernatant and solid fraction, were diluted 10 fold in $1 \mathrm{M} \mathrm{NaAc}$ buffer at pH 4.8 and left at room temperature for $1 \mathrm{~h}$, then the enzymatic activity of Cel7A, Cel7B and $\beta$-glucosidase were determined using the methylumbelliferyl assay (see Section 2.2.1). All experiments were performed in duplicate and repeated twice; the mean values and standard deviations were calculated.

\subsection{Statistical analysis}

The statistical analyses were performed using GraphPad Prism version 5 for Windows, GraphPad Software, San Diego, California, USA. The values reported in the figures are the average of duplicate experiments. Error bars represent \pm standard deviations.

\section{Results and discussion}

\subsection{Hydrolysis and fermentation}

Hydrothermally pretreated wheat straw was hydrolysed using the two different commercial cellulases, Celluclast and Cellic. The concentrations of glucose, cellobiose and ethanol during hydrolysis and fermentation are shown in Fig. 1. The enzyme preparations differ significantly in their ability to convert cellulose, Cellic being more efficient than Celluclast. Thus, we observed that using an enzyme loading of $10 \mathrm{FPU} / \mathrm{g}$ cellulose, Cellic was able to convert $>98 \%$ of glucans (Fig. 1C), whereas using Celluclast without $\beta$ glucosidase supplementation the soluble sugars yield reached only $52 \%$, after $96 \mathrm{~h}$ of hydrolysis (Fig. 1B). Supplementing Celluclast with $\beta$-glucosidase significantly improved the overall hydrolysis yield, a conversion of $81 \%$ being reached (Fig. 1A). Although similar enzyme loads (expressed in FPU) were used, Cellic proves to hydrolyse wheat straw much more effectively.

As could be expected, the ethanol production is roughly proportional to the sugar conversion observed in each case (Fig. 1).

\subsection{Enzyme stability and solid-liquid distribution}

The analysis of the adsorption profiles of specific enzyme components (Cel7A, Cel7B and $\beta$-glucosidase) was performed by measuring the individual enzyme activities found in the liquid and solid phases during hydrolysis and fermentation (Fig. 2). The stability of the commercial preparations throughout the process was also analysed measuring the total enzyme activity (liquid and solid phases), as this is of most relevance regarding enzyme recycling.

\subsubsection{Celluclast}

The soluble Cel7A (about $26-28 \%$ of the original load) and Cel7B (about $31-38 \%$ of original load) activities were relatively low as the hydrolysis ( $96 \mathrm{~h}$ ) and fermentation ( $48 \mathrm{~h}$ ) proceeded (Fig. 2A and B). Contrary to the findings by Tu et al. [31], who observed a continuous release of enzymes into liquid phase as the reaction proceeds, after a high initial adsorption, in our experiments a significant amount 

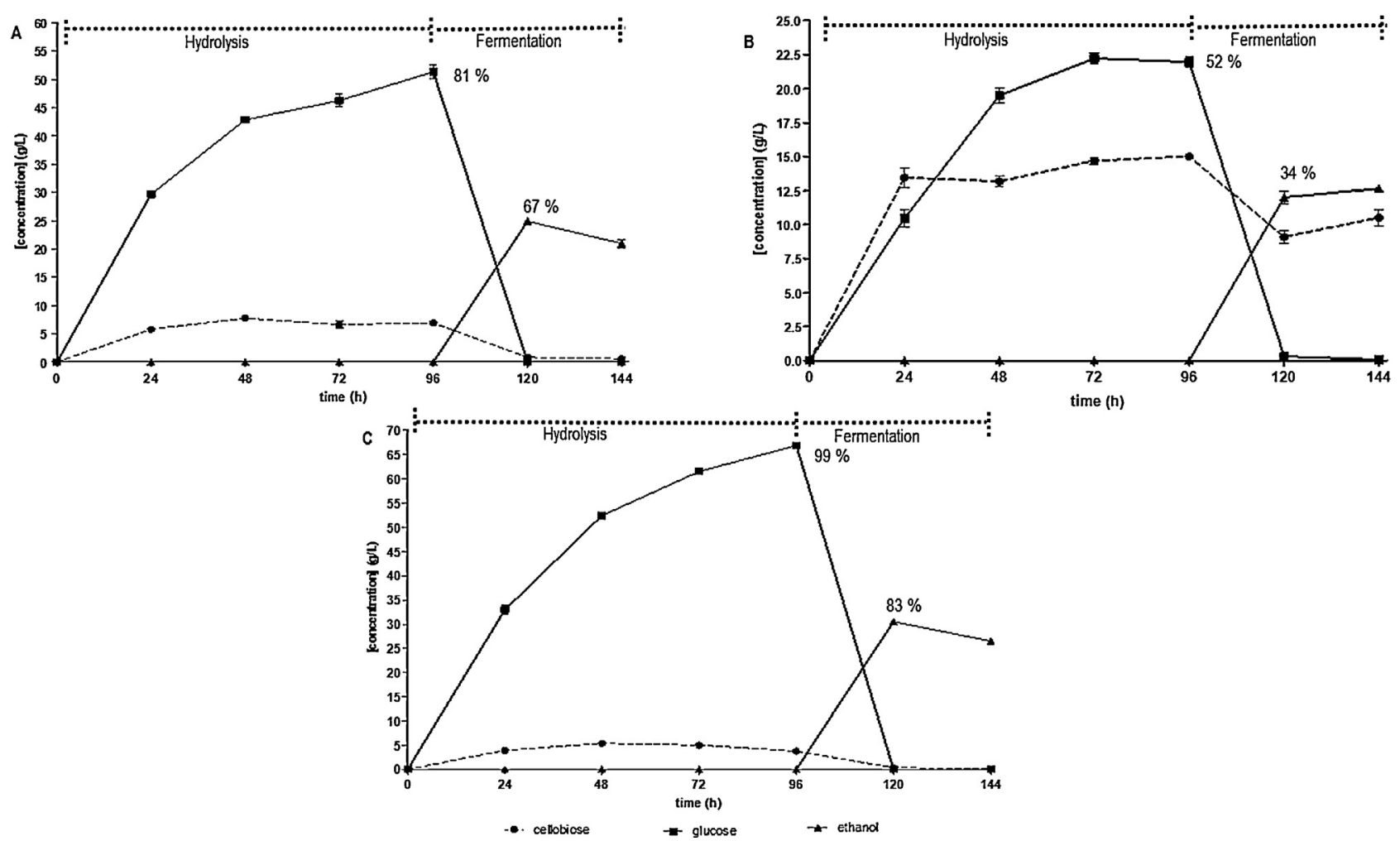

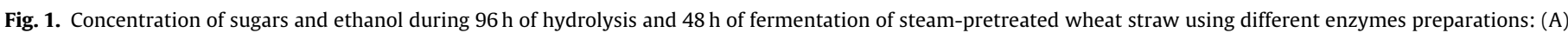

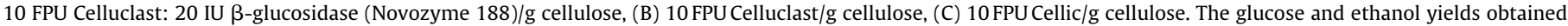
after 96 and $120 \mathrm{~h}$, respectively, are shown in the graph.
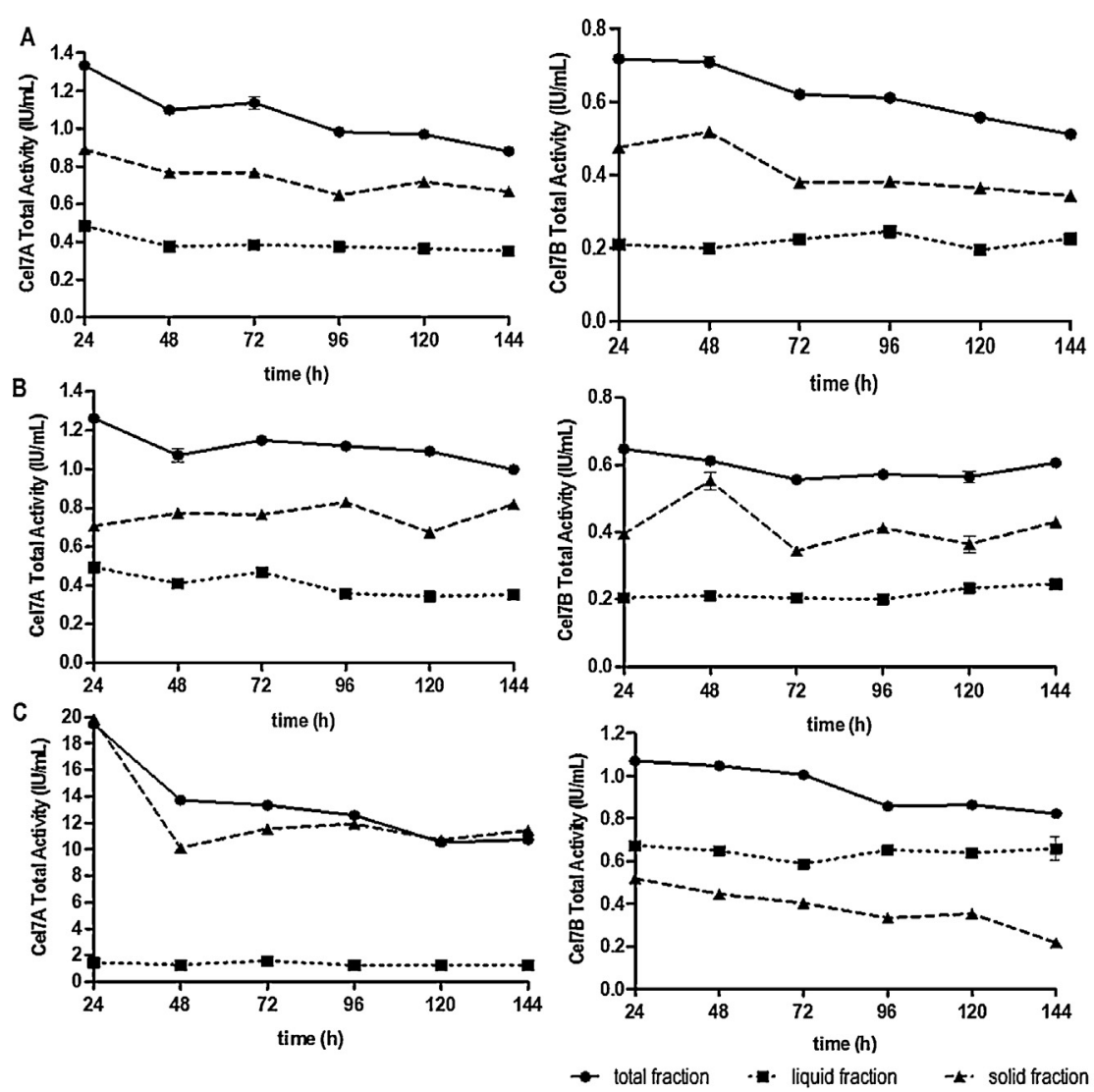

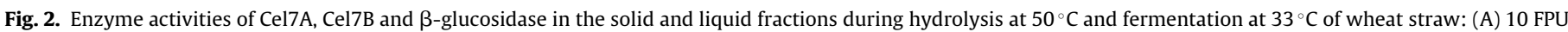
Celluclast: 20 IU $\beta$-glucosidase (Novozyme 188)/g cellulose; (B) 10 FPU Celluclast/g cellulose, (C) 10 FPU Cellic/g cellulose.
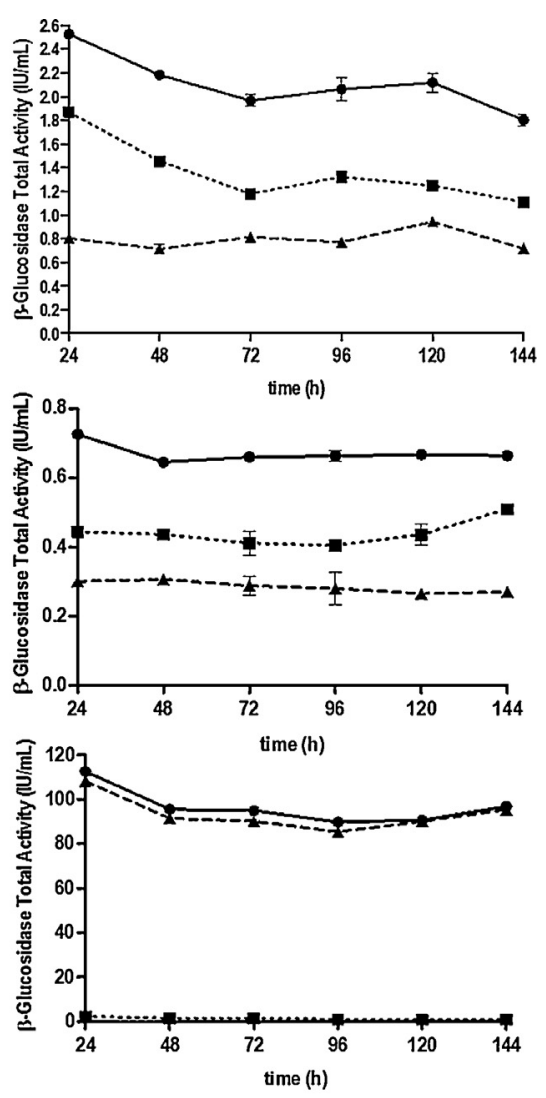


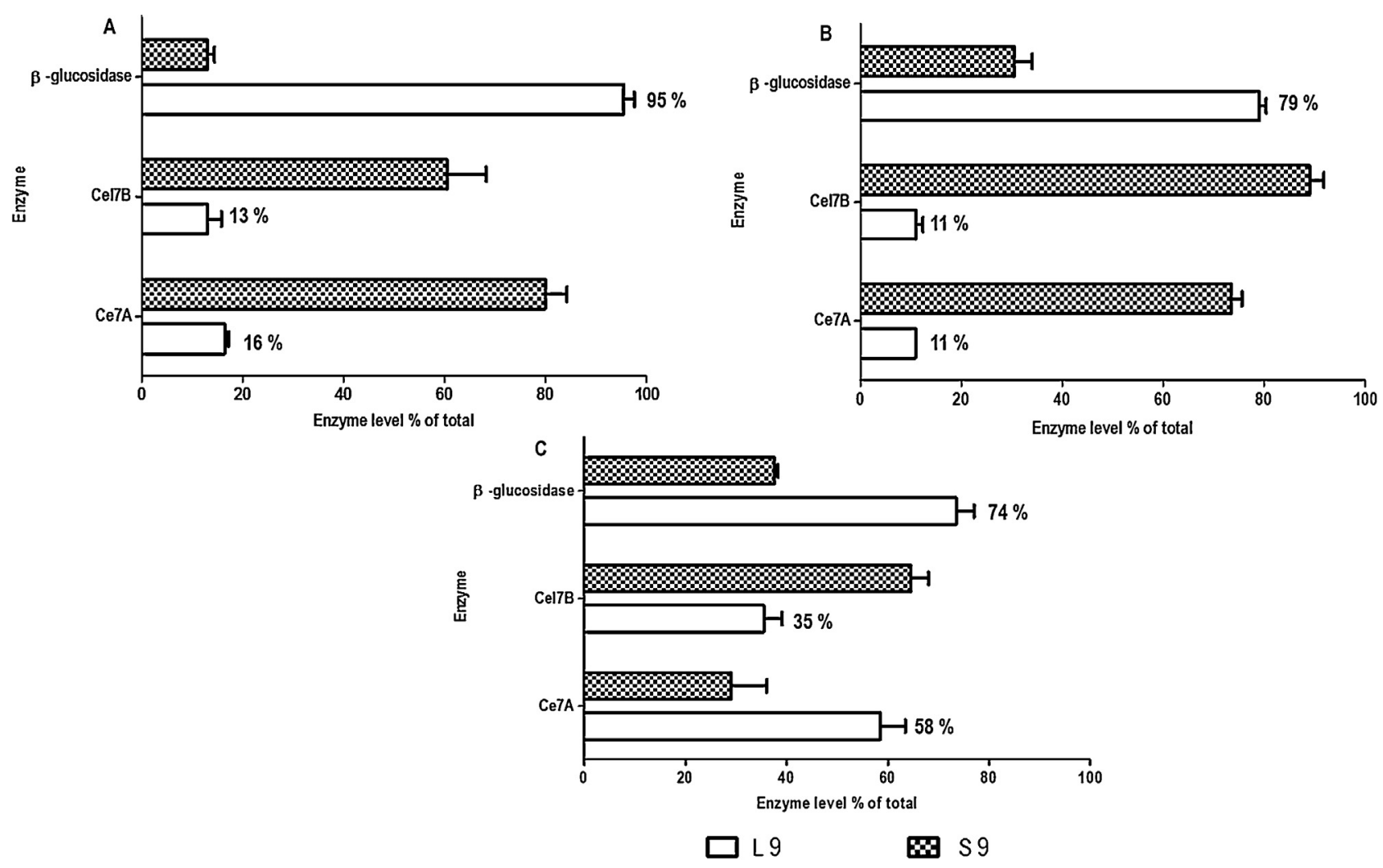

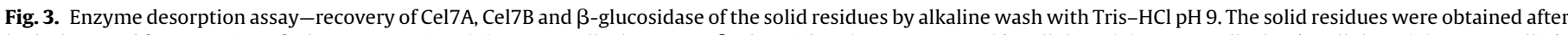

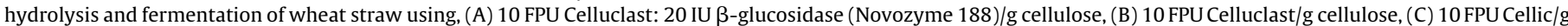
cellulose. L 9 and S 9 correspond to the enzymes recovered from the liquid and solid fractions after alkaline wash, respectively.

of active Cel7A and Cel7B remained attached to the solid residue (Fig. 2A and B). Actually, the proportion of enzyme activity adsorbed on the biomass remains fairly constant over time. Quite probably, after $144 \mathrm{~h}$ of hydrolysis/fermentation there is still a significant amount of undigested cellulose, which may be responsible for the significant adsorption of enzymes. Indeed, to a higher conversion reached using Celluclast supplemented with $\beta$-glucosidase $(81 \%$ as compared to $52 \%$ without $\beta$-glucosidase-Fig. $1 \mathrm{~A}$ and $\mathrm{B}$ ), corresponds a lower amount of adsorbed enzymes in the solid fraction ( $0.67 \mathrm{IU} / \mathrm{mL}$ of Cel7A and $0.34 \mathrm{IU} / \mathrm{mL}$ of Cel7B-Fig. 2A, as compared to $0.82 \mathrm{IU} / \mathrm{mL}$ and $0.43 \mathrm{IU} / \mathrm{mL}$, respectively-Fig. $2 \mathrm{~B}$ ). Indeed, in previous work Rodrigues et al. [10] and in Fig. 5C and D L 4.8 versus S 4.8 we demonstrated that Celluclast has a much higher affinity for cellulose than for lignin.

A larger amount of free $\beta$-glucosidase was observed in liquid fraction, about $60-70 \%$ of the original activity (Fig. 2A and $B)$. This enzyme does not have a cellulose-binding domain (CDB), thus not exhibiting a high affinity to the solid cellulosic substrates. After $144 \mathrm{~h}$, a significant loss of activity was observed. According to different studies (Rodrigues et al. [10,11], Chylenski et al. [22] and Lindedam et al. [13]), thermal denaturation is responsible for the lack of stability of the enzymes. Respectively $66 \%, 71 \%$ and $71 \%$ of the original loading Cel7A, Cel7B and $\beta-$ glucosidase activities in the supplemented Celluclast, and 79\%, $94 \%$, $91 \%$ in the non-supplemented formulation, were recovered (Fig. $2 \mathrm{~A}$ and B). The faster loss of activity in the supplemented Celluclast may be assigned to the lower stability of the $\beta$-glucosidase from Novozymes 188 (Fig. 2A and B).

\subsubsection{Cellic $^{\circledR} \mathrm{CTec} 2$}

The adsorption behaviour of Cellic was found to be much different from that of Celluclast. The free Cel7A and $\beta$-glucosidase activities in the supernatant is practically zero and remained constant during the whole process: about $6 \%$ of Cel7A and $1 \%$ of $\beta$-glucosidase of the initial load, even though practically all the polysaccharides were hydrolysed (Fig. 2C). Interestingly, $\beta$-glucosidase exhibit a high affinity for the solid residue, as reported previously by Haven and Jørgensen [32]. The low enzyme activities in the supernatant may to be caused by the high affinity for lignin. This interpretation was supported by the enzyme adsorption/desorption assay on pure cellulose and lignin (see Section 3.3).

A significant loss of activity can be observed over time, for all three enzymes (Fig. 2C). At the end of the experiment, about $55 \%, 77 \%$ and $86 \%$ of the original Cel7A, Cel7B and $\beta$-glucosidase activities were recovered, respectively. Cellic enzymes seems to significantly deactivate over the long residence time.

It may be noticed that Cel7A is more unstable than Cel7B and $\beta$-glucosidase, which is in accordance with findings of Gunjikar et al. [23] and Ye et al. [24], who demonstrated that Cel7B and $\beta$-glucosidase are less denatured by shear forces and therefore more stable than Cel7A. Also, $\beta$-glucosidase from Cellic seems to be more stable at $50^{\circ} \mathrm{C}$ than the Aspergillus niger $\beta$-glucosidase from Novozyme 188 (Fig. 2A and C).

\subsection{Enzyme recycling}

The cost of cellulases is among the greatest obstacles to the large-scale implementation of cellulose derived biofuels. In the present study, we observed that a large fraction of the active cellulases remain bound to the solid residue after hydrolysis and fermentation of wheat straw (Fig. 2). We attempted to recover the enzymes by pH switch (single step of alkaline wash) using the method previously described by Rodrigues et al. [10]. 
The recovery of Cel7A and Cel7B from Celluclast - with and without addition of $\beta$-glucosidase - by alkaline wash at $\mathrm{pH} 9$ was relatively poor, only $11-16 \%$ and $11-13 \%$ being removed from the final residue obtained after hydrolysis and fermentation, respectively (Fig. 3A and B). According to our previous observations [10] (further confirmed here as shown below on Fig. $5 C$ and D), the presence of cellulose in the residue represents an obstacle for the efficient desorption using alkaline washing.

As a matter of fact, the results shown in Fig. 4 - obtained by performing an alkaline desorption trial every $24 \mathrm{~h}$ along the hydrolysis and fermentation process - clearly demonstrate that alkaline treatment was more efficient in removing enzymes from lignin than from cellulose. Indeed, by increasing the cellulose conversion (from 74 to $100 \%$, respectively at 24 and $168 \mathrm{~h}$ ), a more efficient desorption of Celluclast by alkaline washing was made possible (from 15\% up to $68 \%$ ).

Also in the case of Cellic a substantial portion of the enzyme was still adsorbed to the solid residue-in this case practically only lignin, since higher conversion yields have been reached. The yield of recovered enzyme obtained after alkaline wash was 58\%, 35\% and 74\%, respectively for Cel7A, Cel7B and $\beta$-glucosidase (Fig. 3C, column $\mathrm{L}$ ). In order to better clarify the influence of cellulose and lignin in this process, we performed desorption assay by alkaline wash using pure lignin and cellulose CF11 (Whatman). For Cellic Cel7A, a considerable amount of the enzyme (76\%) was desorbed by alkaline wash from cellulose CF11 (Whatman) (Fig. 5A). Interestingly, for Celluclast Cel7A, only $42 \%$ of the adsorbed enzyme was recovered (Fig. 5C). These results reinforce our previous statement

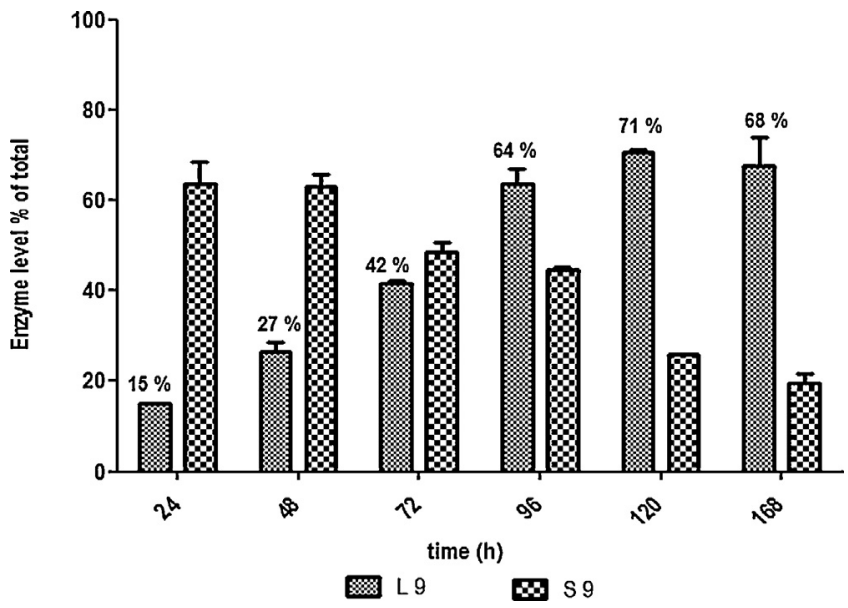

Fig. 4. Enzyme desorption assay-recovery of enzyme activity of Cel7A desorbed from the solid residue after alkaline wash. The solid residues was obtained during $72 \mathrm{~h}$ of hydrolysis followed by $96 \mathrm{~h}$ fermentation of wheat straw with $5 \%(\mathrm{w} / \mathrm{v})$ dry matter, $\mathrm{pH} 4.8,150 \mathrm{rpm}$ at $37^{\circ} \mathrm{C}$, and loading of Celluclast and $\beta$-glucosidase Novozyme 188 preparation of 25 FPU: $50 \mathrm{IU} / \mathrm{g}$ cellulose. The hydrolysis yield obtained was $74 \%, 96 \%$ and $100 \%$ at 24,48 and $72 \mathrm{~h}$, respectively. L 9 and S 9 correspond to the liquid and solid enzyme level after alkaline wash, respectively.

that Cel7A from Celluclast and Cellic bear a rather distinct affinity for cellulose, making its recovery by alkaline desorption much more difficult in the case of Celluclast.
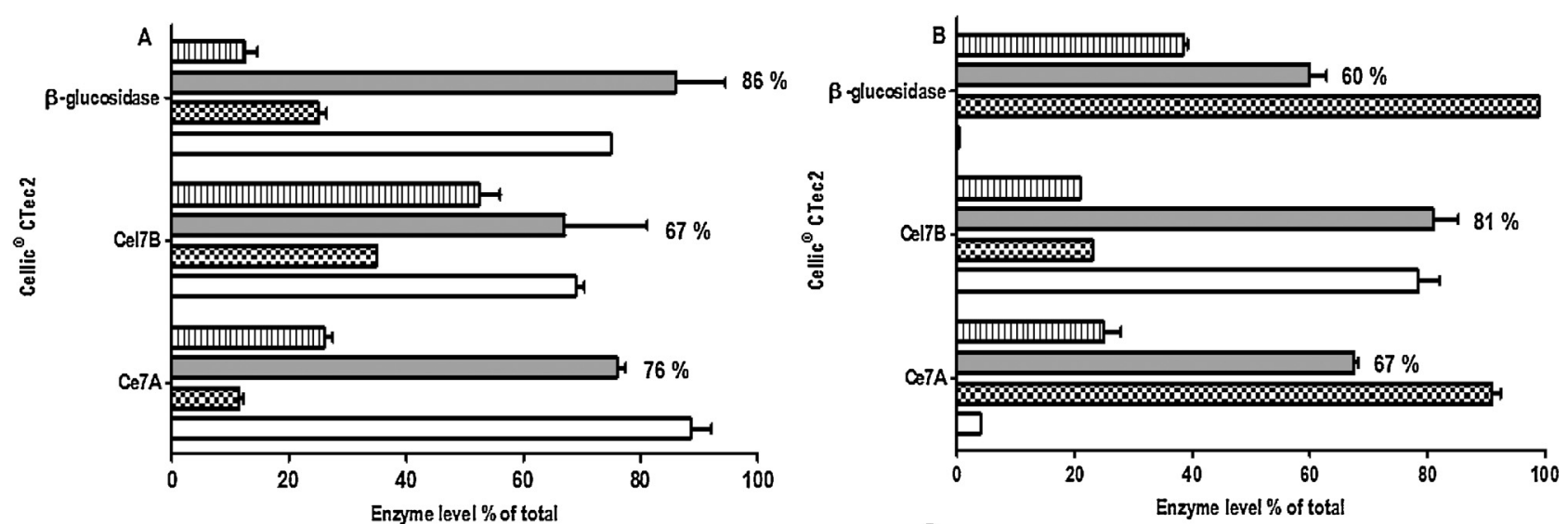

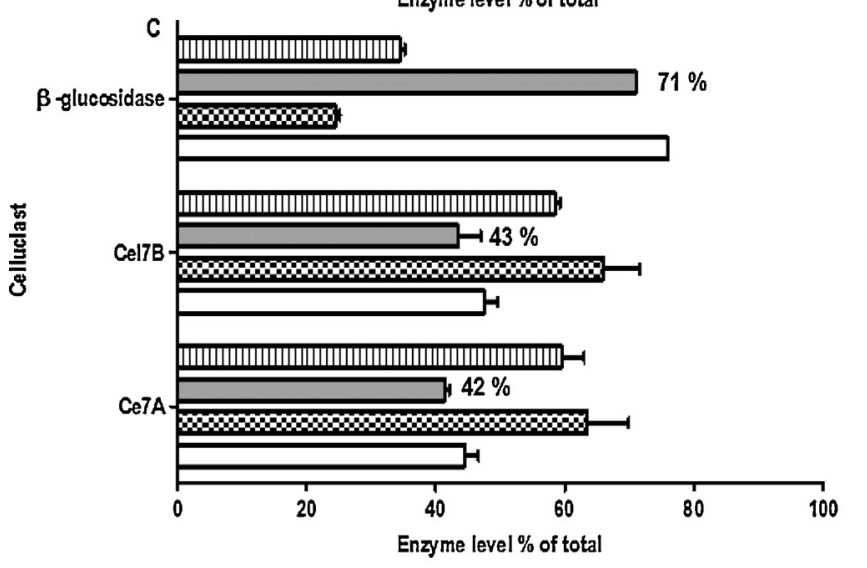

$\square \mathrm{L} 4.8$

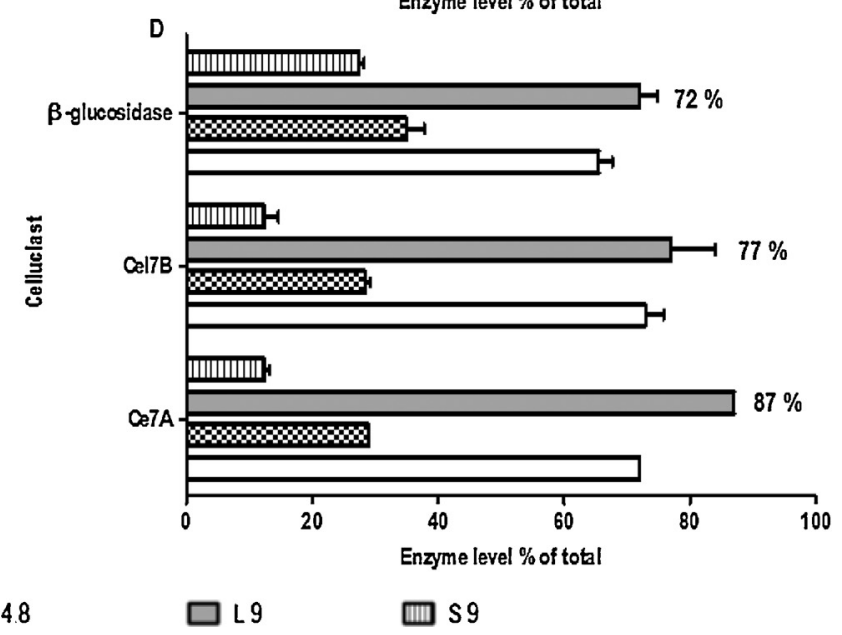

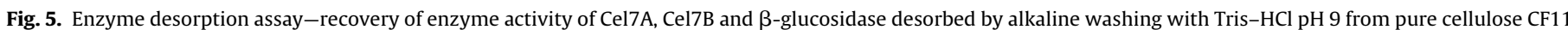
(Whatman) and pure lignin with: (A) $10 \mathrm{FPU}$ Cellic/g cellulose CF11; (B) $10 \mathrm{FPU}$ Cellic/g pure lignin; (C) $10 \mathrm{FPU}$ Celluclast/g cellulose CF11; (D) 10 FPU Celluclast/g pure lignin L 4.8 and S 4.8 correspond to the liquid and solid enzyme activity before alkaline wash, respectively, while L 9 and S 9 correspond to the liquid and solid enzyme activity after alkaline wash, respectively. 
It was also observed that the enzyme Cel7A and $\beta$-glucosidase found on Cellic has a high affinity for pure lignin, as compared to the homologous enzymes from Celluclast (Fig. 5B and D, columns L 4.8 and S 4.8). Despite the high affinity of Cellic for lignin, the alkaline desorption has the ability to remove these enzymes (recovery of 67 and $60 \%$, respectively-Fig. $5 \mathrm{~B}$ ).

Therefore, we demonstrated that alkaline treatment is more efficient in removing Celluclast enzymes from pure lignin, rather than from cellulose. The recovery yield from pure lignin was $87 \%$, $77 \%$ and $72 \%$ for Cel7A, Cel7B and $\beta$-glucosidase, respectively (Fig. 5D). Also, we demonstrated that the alkaline treatment efficiently removes the Cellic enzymes from both lignin and cellulose.

\section{Conclusions}

Cellic and Celluclast have distinct properties, concerning not only activity but also denaturation rate and adsorption on cellulose and lignin. Results indicated that a significant amount of active cellulase remained adsorbed to the solid residue during hydrolysis. Cellic is a more effective catalyst but it is also more sensitive to deactivation than Celluclast. The distribution of Cel7A and $\beta$ glucosidase between the solid and liquid phase was very different depending on the formulation. The adsorbed enzymes may be successfully recovered by alkaline wash. However, increasing the rate of cellulose conversion rendered the technique of alkaline desorption much more efficient, due to easier removal of enzymes from lignin than from cellulose. In addition to thermostability, one striking and relevant feature differentiates Celluclast and Cellic regarding recycling: while Celluclast can be recovered from the liquid phase as long as cellulose conversion is complete (as demonstrated in our previous work [10]), Cellic remains adsorbed onto the residual lignin. Thus, although being a much more effective enzyme formulation, Cellic is much more challenging enzyme to recycle, since it bears lower thermostability and higher affinity towards lignin. While one may conceive recycling significant amounts of Celluclast out of the liquid phase only, in the case of Cellic an extraction of the enzymes from the solid residue is mandatory.

Finally, it must be remarked that the development of improved enzymes should take in account not only their kinetic properties but also the stability and affinity towards the reaction residue, in order to make recycling possible. Indeed, the fast expansion of the biorefinery concept will increase extraordinarily the cellulases market. The potential for recycling will certainly be a competitive asset for the cellulase formulations of the future.

\section{Conflict of interest}

The authors declare that they have no conflict of interest.

\section{Acknowledgements}

The authors acknowledge funding through FP7 KACELLE (Kalundborg Cellulosic Ethanol, Grant no. 239379) project for supporting this work. We also thank Dr. Lucília Domingues for supplying the yeast Saccharomyces cerevisiae CEN PK 113 wild type.

The authors thank the FCT Strategic Project of UID/BIO/ 04469/2013 unit, the project RECI/BBB-EBI/0179/2012 (FCOMP01-0124-FEDER-027462) and the Project "BioEnv-Biotechnology and Bioengineering for a sustainable world”, REF. NORTE-07-0124FEDER-000048, co-funded by the Programa Operacional Regional do Norte (ON.2-O Novo Norte), QREN, FEDER.

\section{References}

[1] A. Pribowo, V. Arantes, J.N. Saddler, The adsorption and enzyme activity profiles of specific Trichoderma reesei cellulose/xylanase components when hydrolysing steam pretreated corn stover, Enzyme Microb. Technol. 50 (2012) 195-203.

[2] J. Larsen, M.D. Jeppesen, Rapid and low cost enzymatic full conversion of lignocellulosic biomass. WO 2013050806 A1, (2013).

[3] J. Xu, H. Chen, A novel stepwise recovery of cellulose adsorbed to the residual subsrate after hydrolysis of the steam exploded wheat straw, Appl. Biochem. Biotechnol. 143 (2007) 93-100.

[4] Z. Zhu, N. Sathitsuksanoh, Y.-H.P. Zhang, Direct quantitative determination of adsorbed cellulase on lignocellulosic biomass with its application to study cellulose desorption for potential recycling, Analyst 134 (2009) 2267-2272.

[5] B.P. Lamsal, R. Madl, K. Tsakpunidis, Comparison of feedstock pretreatment performance and its effect on soluble sugar availability, Bioenergy Res. 4 (2011) 193-200.

[6] D.E. Otter, P.A. Munro, G.K. Scott, R. Geddes, Elution of Trichoderma reesei cellulase from cellulose by $\mathrm{pH}$ adjustment with sodium hydroxide, Biotechnol. Lett. 6 (1984) 369-374

[7] D.E. Otter, P.A. Munro, G.K. Scott, R. Geddes, Desorption of Trichoderma reesei cellulose from cellulose by a range of desorbents, Biotechnol. Bioeng. 34 (1989) 291-298.

[8] B. Qi, X. Chen, Y. Su, Y. Wan, Enzyme adsorption and recycling during hydrolysis of wheat straw lignocelluloses, Bioresour. Technol. 102 (2011) 2881-2889.

[9] R. Du, R. Su, X. Li, X. Tantai, Z. Liu, J. Yang, W. Qi, Z. He, Controlled adsorption of cellulase onto pretreated corncob by pH adjustment, Cellulose 19 (2012) $371-380$.

[10] A.C. Rodrigues, A.F. Leitão, S. Moreira, C. Felby, M. Gama, Recycling of cellulases in lignocellulosic hydrolysates using alkaline elution, Bioresour. Technol. 110 (2012) 526-533.

[11] A.C. Rodrigues, C. Felby, M. Gama, Cellulase stability, adsorption/desorption profiles and recycling during succesive cycles of hydrolysis and fermentation of wheat straw, Bioresour. Technol. 156 (2014) 163-169.

[12] M. Tu, X. Zhang, M. Paice, P. MacFarlane, J.N. Saddler, The potencial of enzyme recycling during the hydrolysis of a mixed softwood feedstock, Bioresour. Technol. 100 (2009) 6407-6415.

[13] J. Lindedam, M. Haven, P. Chylenski, H. Jørgensen, C. Felby, Recycling cellulases for cellulosic ethanol production at industrial relevant conditions: potential and temperature dependency at high solid processes, Bioresour. Technol. 148 (2013) 180-188.

[14] D. Lee, A.H.C. Yu, J.N. Saddler, Evaluation of cellulase recycling strategies for the hydrolysis of lignocellulosic subsrates, Biotechnol. Bioeng. 45 (1995) 328-336.

[15] L.P. Ramos, C. Breuil, J.N. Saddler, The use of enzyme recycling and the influence of sugar accumulation on cellulose hydrolysis by Trichoderma cellulases, Enzyme Microb. Technol. 15 (1993) 19-25

[16] M.J. Zhang, R.X. Su, Q. Li, W. Qi, Z.M. He, Enzymatic saccharification of pretreated corn stover in a fed-batch membrane bioreactor, Bioenergy Res. 4 (2011) 134-140.

[17] H. Palonen, F. Tjerneld, G. Zacchi, M. Tenkanen, Adsorption of Trichoderma reesei $\mathrm{CBH}$ I and EG II and their catalytic domains on steam pretreated softwood and isolated lignin, J. Biotechnol. 107 (2004) 65-72.

[18] B.L. Rad, R. Yazdanparast, Desorption of the cellulose systems of Trichoderma reesei and a Botrytis sp. from Avicel, Biotechnol. Technol. 12 (1998) 693-696.

[19] M.V. Desphande, K.-E. Erikson, Reutilization of enzymes for saccharification of lignocelluosic materials, Enzyme Microb. Technol. 6 (1984) 338-340.

[20] B. Sipos, D. Dienes, Á. Schleicher, R. Perazzini, C. Crestini, M. Siika-aho, K. Réczey, Hydrolysis efficiency and enzyme adsorption on steam-pretreated spruce in the presence of poly(ethylene glycol), Enzyme Microb. Technol. 47 (2010) 84-90

[21] G. Hu, J.A. Heitmann, O.J. Rojas, J.J. Pawlak, D.S. Argyropoulos, Monitoring cellulase protein adsorption and recovery using SDS-PAGE, Ind. Eng. Chem. Res. 49 (2010) 8333-8338.

[22] P. Chylenski, C. Felby, M.Ø. Haven, M. Gama, M.J. Selig, Precipitation of Trichoderma reesei commercial cellulose preparations under standard enzymatic hydrolysis conditions for lignocelluloses, Biotechnol. Lett. 34 (2012) 1475-1482

[23] T.P. Gunjikar, S.B. Sawant, J.B. Joshi, Shear deactivation of cellulase, exoglucanase, endoglucanase and $\beta$-glucosidase in mechanically agitated reactor, Biotechnol. Prog. 17 (2001) 1166-1168.

[24] Z. Ye, K.M. Hatfield, R.E. Berson, Deactivation of individual cellulose components, Bioresour. Technol. 106 (2012) 133-137.

[25] B. Adney, J. Baker, Measurement of Cellulase Activities Laboratory Analytical Procedure. NREL LAP-006, (1996).

[26] M.Ø. Petersen, J. Larsen, M.H. Thomsen, Optimization of hydrothermal pretreatment of wheat straw for production of bioethanol at low water consumption without addition of chemicals, Biomass Bioenergy 33 (2009) $834-840$.

[27] M.J. Bailey, J. Tähtiharju, Efficient cellulose production by Trichoderma reese in continuous cultivation on lactose medium with a computer-controlled feeding strategy, Appl. Microbiol. Biotechnol. 62 (2003) $156-162$.

[28] Van, H. Tilbeurgh, M. Claeyssens, C.K. De Bruyne, The use of 4-methylumbelliferyl and other chromophoric glycosides in the study of cellulolytic enzymes, FEBS Lett. 149 (1982) 152-156. 
[29] L. Browing in: B.L. Browing (Ed.), Methods of Wood Chemistry, Wiley, New York, 1967

[30] N. Dowe, J. McMillan, SSF Experimental Protocols-Lignocellulosic Biomass Hydrolysis and Fermentation. NREL Analytical Procedure, National Renewable Energy Laboratory, Golden, CO, USA, 2001.
[31] M. Tu, R.P. Chandra, J.N. Saddler, Evaluating the distribution of cellulases and the recycling of free cellulases during the hydrolysis of lignocellulosic substrates, Biotechnol. Prog. 23 (2007) 398-406.

[32] M.Ø. Haven, H. Jørgensen, Adsorption of $\beta$-glucosidases in two commercials preparations onto pretreated biomass and lignin, Biotechnol. Biofuels 6 (2013) 165 